\title{
Microfacies Patterns and Depositional Environments of the Sarvak Formation in the Abadan Plain, Southwest of Zagros, Iran
}

\author{
Shahab Soleimani Asl, Mohsen Aleali* \\ Department of Geology, Science and Research Branch, Islamic Azad University, Tehran, Iran \\ Email: *m.aleali@srbiau.ac.ir
}

Received 21 November 2015; accepted 27 March 2016; published 30 March 2016

Copyright (C) 2016 by authors and Scientific Research Publishing Inc.

This work is licensed under the Creative Commons Attribution International License (CC BY). http://creativecommons.org/licenses/by/4.0/

(c) (i) Open Access

\section{Abstract}

The Sarvak Formation is the second major oil-bearing reservoir in the south and south west of Iran. The Middle Cretaceous Sarvak formation in the Zagros Mountains (Zagros Basin) is mainly composed of carbonate sequences. Based on facies studied, thirteen microfacies were recognized in the studied area, which were categorized in the three facies groups: including inner ramp, mid ramp and outer ramp. Evidences such as the gradual changes in the facies (basin slope), the absence of extensive uninterrupted barrier reef, the lack of calciturbidite and gravity sediments as well as the high proportion of grain-supported indicated that the Sarvak Formation was deposited in the ramp like depositional system, particularly on an inner ramp setting. Inner ramp facies group is the principal setting and subdivided to tidal flat, restricted and unrestricted lagoon as well as shoal sub-environments.

\section{Keywords}

Microfacies, Depositional Environments, Sarvak Formation, Zagros, Iran

\section{Introduction}

Zagros basin is known as one of the most petroliferous regions in the world in term of hydrocarbon potentials [1]. After Asmari Formation that is most important reservoir in Iran, the Sarvak Formation constitutes second largest petroleum reservoir. Sarvak Formation is a part of Bangestan group. The Kazhdumi, Sarvak, Surgah as well as the Ilam Formations with middle to upper Cretaceous age formed the Bangestan group in the south and southwest of Iran [2]. The type section of Sarvak Formation is located in the northwest of the Behbahan city in

\footnotetext{
"Corresponding author.
}

How to cite this paper: Asl, S.S. and Aleali, M. (2016) Microfacies Patterns and Depositional Environments of the Sarvak Formation in the Abadan Plain, Southwest of Zagros, Iran. Open Journal of Geology, 6, 201-209. 
Khuzestan province. In the type section, Sarvak Formation is composed of over $820 \mathrm{~m}$ of thin, medium bedded and massive limestone containing chert nodules and interbeds of shale. According to distribution of foraminifer contents in the type section [2] mentioned Albian to cenomanian age for Sarvak Formation) [2].

The lower boundary of the Sarvak Formation with the Kazhdumi Formation is sharp, in the Zagros province. The upper lithostragraphic unit of Sarvak carbonates is different in various parts of Zagros. In some parts of Zagros Ilam Formation and in the other parts Gurpi Formation covers Sarvak limestones. Because of reservoir significance, many authors have been studied geological characteristics of Sarvak Formation in the Zagros basin and Arabian plate [3]-[16].

The aims of current article are 1) assign detailed microfacies type, 2) interpret the facies, 3) determine different setting of facies and 4) delineate depositional environment model.

\section{Geological Setting}

Zagros province that is essentially portion of Alp-Himalaya orogenic belt, known as one of the most important and largest oil-rich regions of the worlds because of abundance of giant and supergiant folds and oil fields as well as numerous salt domes [17]. The Zagros fold and thrust belt with nearly $1800 \mathrm{~km}$ long and $250 \mathrm{~km}$ wide composed of deformed rocks that created in the foreland of the collision between the Arabian Plate and the Iranian Plate [18] [19]. Convergence movement and subduction of Arabian plate beneath the Central Iran block created a series of thrusts and anticlines in the Zagros basins. Folding process has not been stopped in this fold-thrust belt and crust evolution continues in the West of the Zagros Mountains of Iran [20] [21]. According to structural and geological features and stratigraphic characteristics Zagros province divided into three major zones including high Zagros, folded Zagros and Abadan plain (Figure 2) [17]. The Study area (Azadegan anticline) is located on Abadan plain at $80 \mathrm{~km}$ West of Ahvaz city. This anticline is located in the in the Iran-Iraq

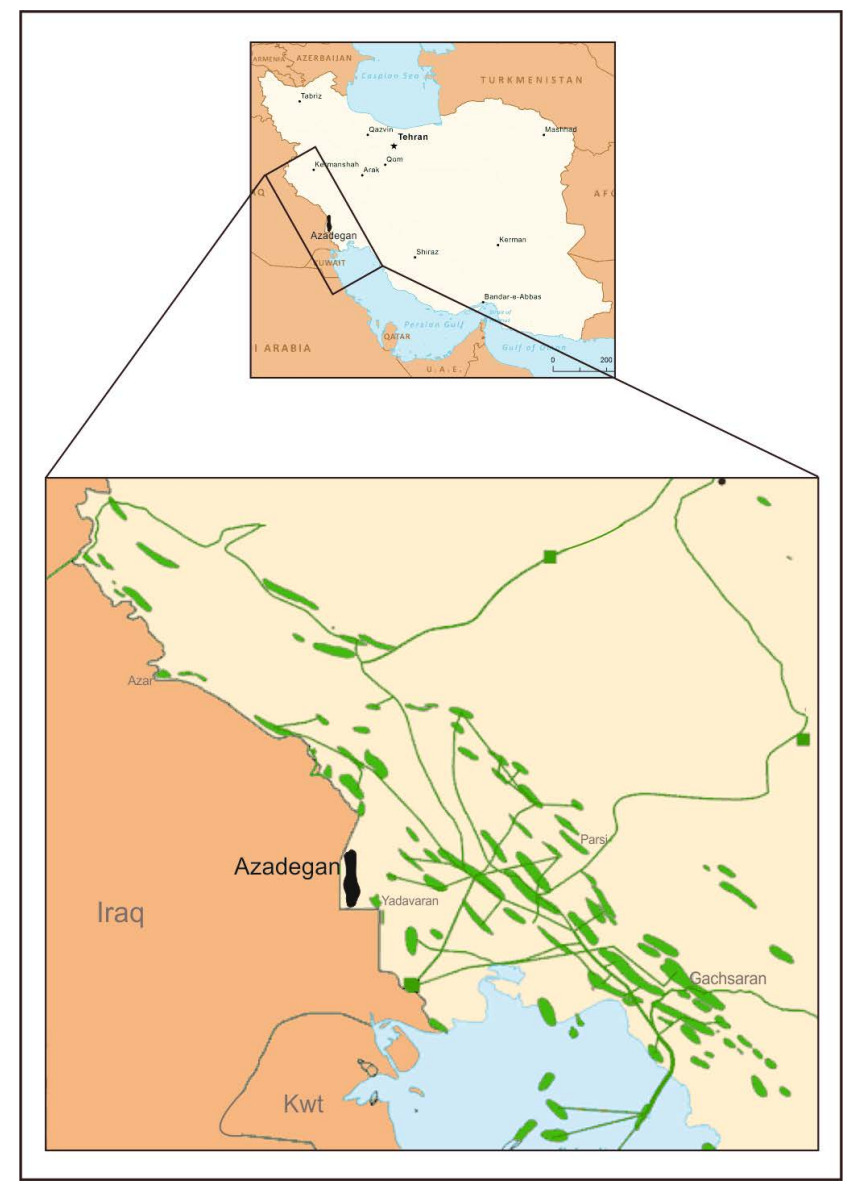

Figure 1. Geographic position of the studied area of the middle cretaceous Sarvak formation in the southwest of the Zagros. 


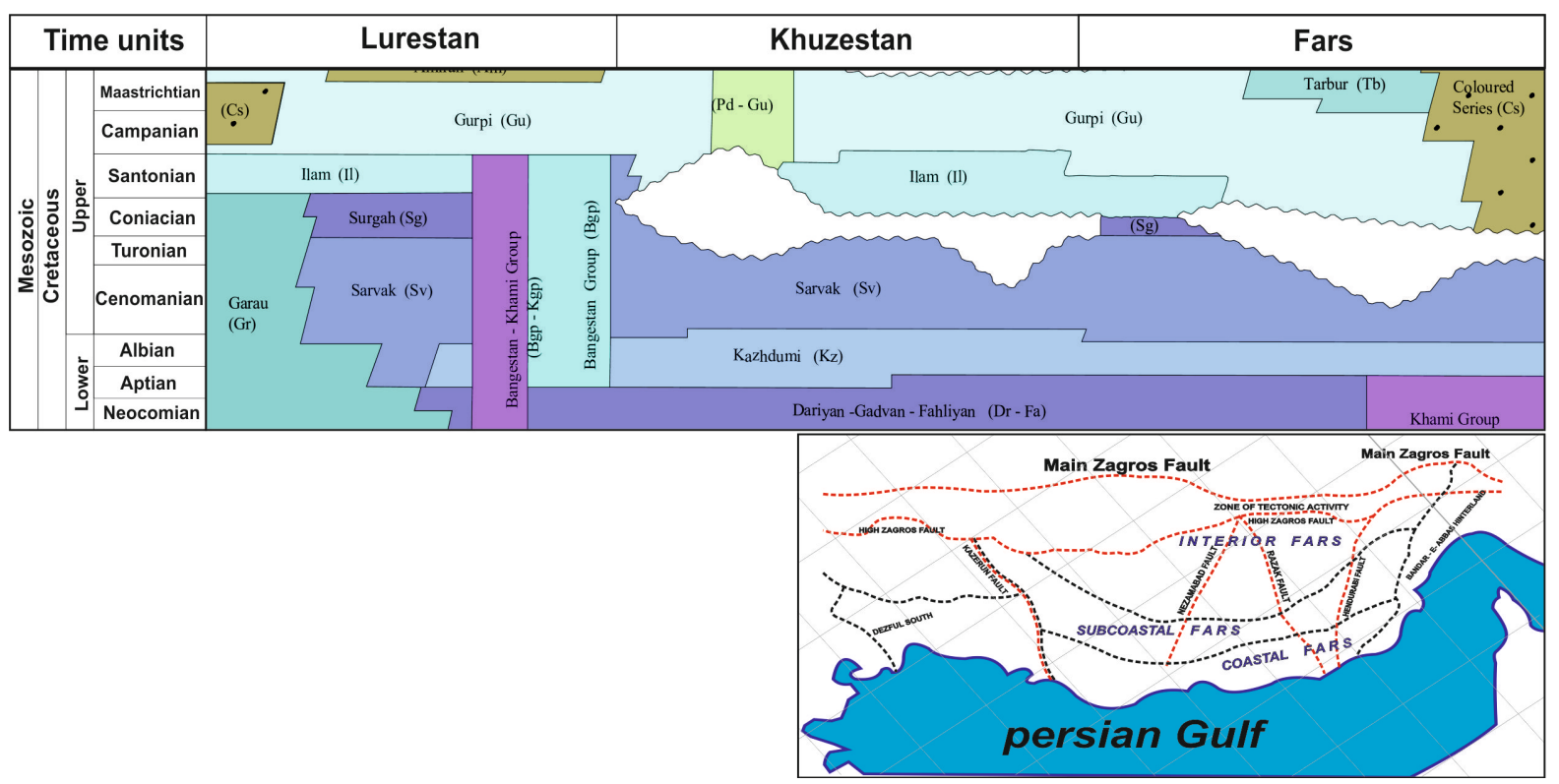

Figure 2. Cretaceous stratigraphy chart of the Zagros basin, modified after [2].

border (Figure 1). The main reservoir Intervals in the Azadegan anticline are Sarvak, Kazhdumi, Gadvan and Fahlian Formations (Figure 2).

\section{Materials and Methods}

The current paper is based on core and petrographic examination of the Sarvak Formation from the azadegan oil field. Three wells in the field were collected and more than 600 thin sections examined to assign sedimentological characteristics, facies types, and depositional model. Whole of thin sections were half-stained with Alizarin Red-S to denotation calcite from dolomite. Carbonate facies analysis is carried out based on Dunham (1962) [22] and Embry and Klovan (1971) [23] carbonate classification models. For determine depositional environments concepts of standard depositional environment models and distribution of facies was used (e.g. [24]-[28]).

\section{Microfacies Description and Interpretation}

Based on petrographic analysis and sedimentology characteristic of the Sarvak Formation 13 microfacies types can be defined into three facies groups. These comprise the inner ramp (A), mid ramp (B) and outer ramp (C) facies group.

\section{A) Inner ramp facies group}

Carbonate deposits of the inner ramp facies group composed of nine microfacies that are belong to the tidal flat, lagoon and shoal sub-environments.

\section{FA1) Fenestral mudstone}

The fenestral mudstone made up of mud supported micritic texture with fenestral fabrics. Skeletal grains are less than $10 \%$ and there are not non-skeletal grains in this facies (Figure 3(a)). An abundance of lime mudstone with fenestral fabrics, bird's eye structure and a lack of skeletal grains indicated that $\mathrm{FA}_{1}$ is belongs to supratidal to intertidal zone [29]-[31].

FA2) Benthic foraminifera sponge spicule wackestone to packstone

This facies consists of mud supported texture with less than $50 \%$ grains. Benthic foraminifers (Such as miliolid and textularia) and sponge spicules are the main skeletal grains. Bivalves and echinoderm fragments as well as peloids are subordinate grains. Bioturbation and micritization are observed in this facies (Figure 3(b)). Based on bioturbated mud supported nature (mudstone to wackestone), presence of benthic foraminifers such as miliolid, micritization of grains can be suggested that this facies forms on restricted lagoon sub-environment [24] [32].

FA3) Bioclast wackestone to mudstone

The matrix of this microfacies is dark brown microcrystalline calcite (micrite). The main allochems are ben- 

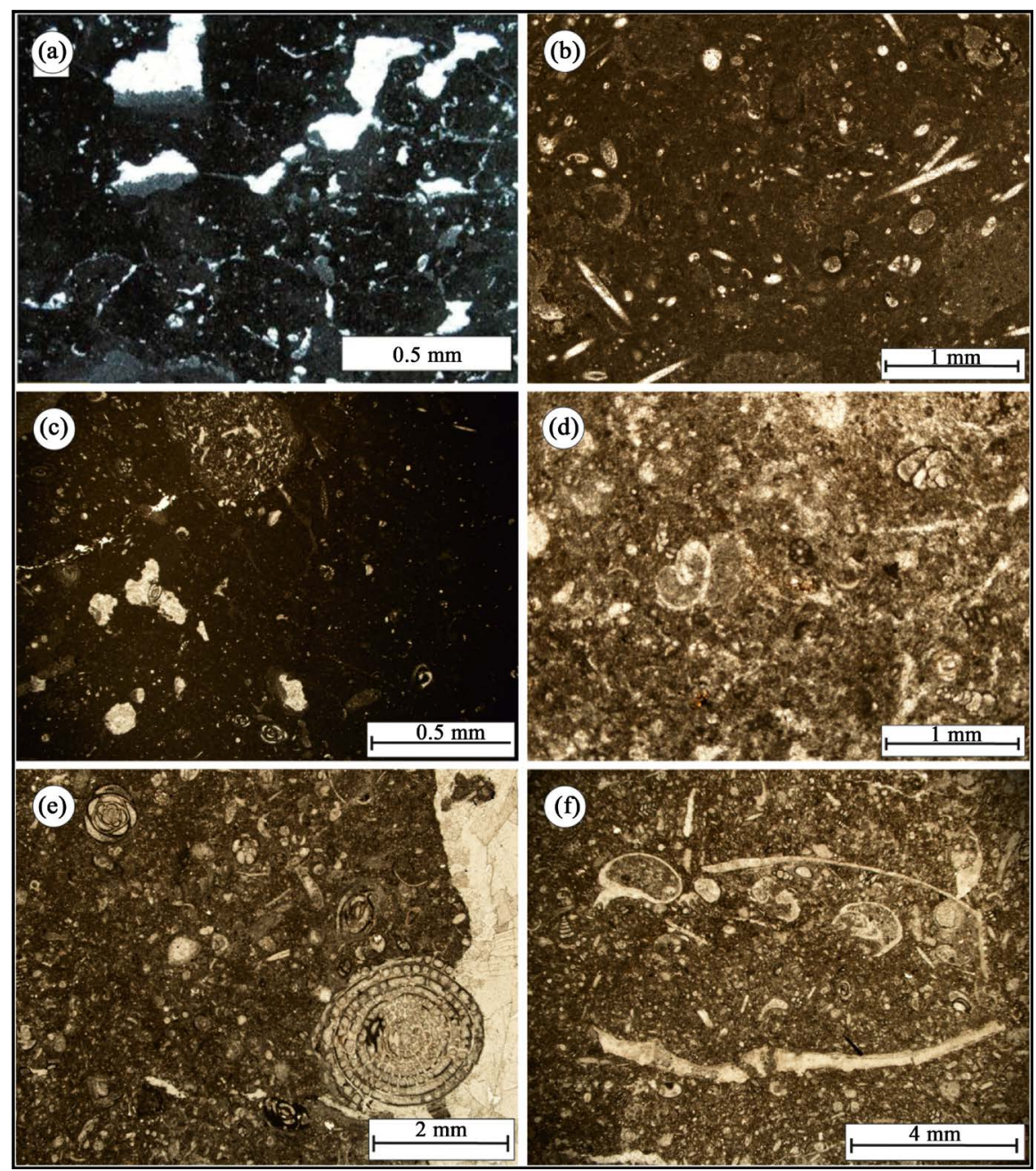

Figure 3. Photomicrographs of the facies types of the Sarvak Formation. (a) Fenestral mudstone; (b) Benthic foraminifera sponge spicule wackestone to packstone; (c) Bioclast wackestone to mudstone; (d) Benthic foraminifera and gastropoda wackestone to packstone; (e) High diversity benthic foraminifera bioclast wackestone to packstone; (f) Large benthic foraminifera rudist debris wackestone to packstone.

thic foraminifera (such as miliolid and alveolina), gastropods, shell fragments together with sponge spicules. Sparse fine grained peloids are subordinate allochems (Figure 3(c)). Geopetal fabric and neomorphism are present. The plentifulness of lime mudstone (micritic texture) and the presence of lagoon fauna particularly porcelaneous-wall benthic foraminifera and gastropoda along with peloid grains indicated that $\mathrm{FA}_{3}$ forms on the low energy restricted lagoon environment [33] [34].

FA4) Benthic foraminifera and gastropoda wackestone to packstone

The main allochems of this microfacies are skeletal constituents such as benthic foraminifera and gastropods. Skeletal constituents include around $30 \%$ to $60 \%$ of grains and indicate variation in size. Other constituents are bivalve debris and peloids. Also, bioturbation and micritization are existed (Figure 3(d)). The occurrence of lime mudstone, lagoon fauna and the abundance of peloids exhibit a shallow subtidal restrict lagoon settings [35]. Micritizied boundaries of grains show boring by micro-organisms such as endolithic algae and microbes. Micritic envelopes of carbonate grains implies to low energy environments and low sedimentation rates [36].

FT5) High diversity benthic foraminifera bioclast wackestone to packstone

This facies is characterized by high diversity of benthic foaminifera. The major benthic foraminifers are miliolid, alveolina, nezzazata and textularia. Rudist debris, ostracods, bivalve shells and green alga along with echinoderms are other skeletal grains (Figure 3(e)). The minor allochems are peloids. High diversity of benthic foraminifers and characteristic of facies showed that $\mathrm{FT}_{5}$ was formed to moderate energy unrestricted lagoon en- 
vironment [28] [35].

FA6) Large benthic foraminifera rudist debris wackestone to packstone

This facies is mainly composed of large benthic foraminifera (15\% to $35 \%$ ) and rudist debris ( $20 \%$ to $45 \%$ ). The size of rudist fragments ranges between 0.5 to $2 \mathrm{~mm}$. the minor grains are bivalve and echinoderm debris in addition to peloid grains (Figure 3(f)). Relative abundant of lagoon fauna, presence of micritic matrix and rudist debris indicated that this facies created in the moderate energy unrestricted lagoon setting [8] [26] [34].

FA7) Bioclast packstone to grainstone

Bioclast packstone to grainstone facies is chiefly composed of skeletal grains. Skeletal grains formed more than $60 \%$ of this facies. Benthic foraminifera (such as miliolid and nezzazata), rudist debris, bivalve and echinoderm fragments are the principal skeletal grains. Peloid grains are observed in this facies. Most of the allochems are covered by a micritic envelope and surrounded by spary calcite cement. The grains are relatively well rounded and sorted (Figure 4(a)). According to the type of grains, the present of micritic envelope and unwashed spary calcite, relatively well sorted and well rounded grains can be said $\mathrm{FA}_{7}$ formed on the leeward shoal environments [24] [28].

\section{FA8) Rudist debris grainstone}

Rudist debris grainstone facies characterized by grain supported texture with richness of rudist fragments the size of rudist debris ranges between 0.5 to $3 \mathrm{~mm}$. benthic foraminifera, bivalve and echinoderm fragments and peloids are subordinate constituents (Figure 4(b), Figure 4(c)). The grain supported nature, lack of mud, large size rudist debris hinted to high-energy of central shoal conditions [3] [37].

\section{FA9) Bioclast grainstone}

The bioclast grainstone mostly consist of skeletal allochems cemented by spary calcite. The dominant allochems are rudist debris, benthic foraminifera, bivalve and echinoderm fragments as well as peloids (minor). The
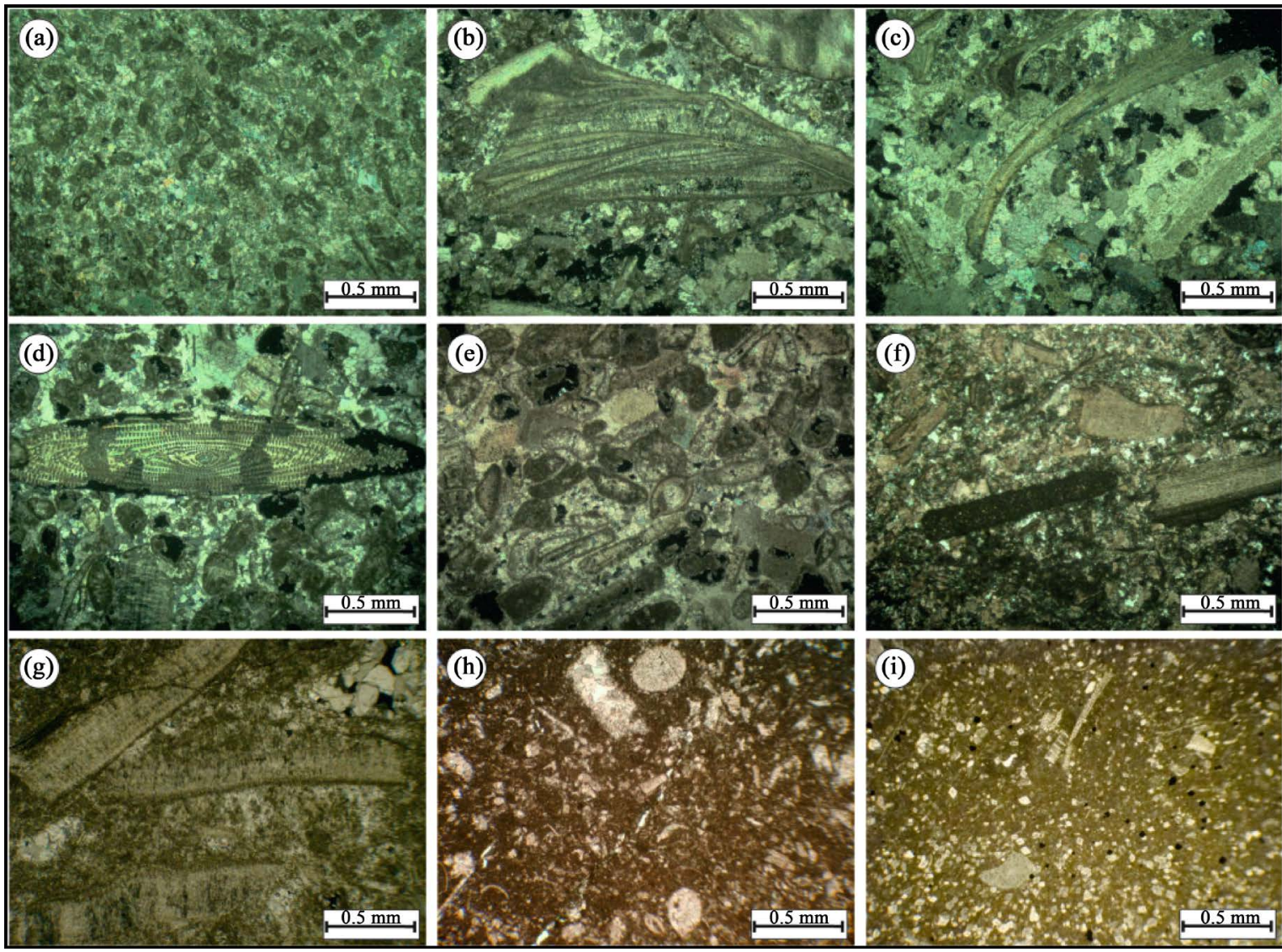

Figure 4. Photomicrographs of the facies types of the Sarvak Formation. (a) Bioclast packstone to grainstone, (b) and (c) Rudist debris grainstone, (d) Bioclast grainstone, (e) Bioclast packstone to grainstone, (f) and (g) Bioclast floatstone to rudstone, (h) Echinoderm bioclast wackestone to packstone, (i) Echinoderm bioclast wackestone to packstone. 
moderate to well sorted rudist debris formed around $40 \%$ of this facies (Figure $4(\mathrm{~d})$ ). Micritic envelope is present in edge of some of the grains. The absence of mud (or lesser mud contents) in this facies mentioned current or wave dominated high-energy shoal environment.

\section{FA10) Bioclast packstone to grainstone}

This facies comprised of microspar to sparite matrix as well as bioclast fragments. The major allochems include rudist debris, echinoderm/crinoids and benthic foraminifera. Components are well sorted and include micritic edges. Rudist debris are neomorphed by sparry calcite (Figure 4(e)). Given the facies evidences such as packstone to grainstone texture, occurrence of carbonate mud and type of fauna propose that FA $\mathrm{A}_{10}$ made up in the moderate energy of the end of inner ramp (terminal portion of the shoal) [26].

\section{B) Middle ramp facies group}

Two microfacies are situated in the middle ramp environment. These include $\mathrm{FB}_{1}$ and $\mathrm{FB}_{2}$.

\section{FB1) Bioclast floatstone to rudstone}

Bioclast floatstone to rudstone mainly comprised of large skeletal fragments such as rudist debris. The major grains are medium to large rudist debris along with echinoid and bivalve fragments. Benthic foraminifera, gastropoda and peloid are minor grains. Rudist debris creates 25\% to 50\% of the components (generally up to 2 $\mathrm{mm}$ in size) (Figure 4(f), Figure 4(g)). According to Embry and Klovan [23] this facies is the result of fragmentation of reef builder structures. This crushed components of reef build up's forms talus deposits in the middle ramp (fore shoal) depositional environment [28].

FB2) Echinoderm bioclast wackestone to packstone

This facies is chiefly consists of rudist debris, echinoderm and bivalve fragments. In addition, benthic foraminifers are minor constituents. Grains are located in the micritic mud background (Figure 4(h)). This facies is belonging to middle part of mid-ramp) [8].

C) Outer ramp facies group

This facies group consists of one microfacies including:

\section{FC1) Bioclast mudstone to wackestone}

This facies belongs to the deepest part of Sarvak Formation in the study area. This mud-supported facies comprised of small rudist, echinoderm and bivalve debris and small foraminifers (Figure 4(i)). The mud-supported nature, a low abundance of benthic fauna and the absence of wave and current patterns show low energy calm environments of the outer ramp (off-shoal) depositional setting [8] [14].

\section{Depositional Environment}

The depositional environment of the Sarvak Formation is various from place to place [7] [8]-[17]. In the some areas depositional system of the Sarvak Formation is introduced as ramp-type platform [15] [16] and in the others shelf-type platform (e.g [3] [8]). The gradual changes in the basin slope, the absence of extensive barrier reef, the lack of calciturbidite and gravity sediments as well as the high proportion of grain-supported facies indicated that Sarvak Formation deposited on a carbonate ramp system with gentle gradient, especially on an inner ramp (Figure 5) (e.g. [26]-[28] [34]).

The Inner ramp setting divided to four sub-environments, including tidal flat, restricted lagoon, open marine lagoon and shoal. The shoal sub-environment was responsible for sedimentation of high-energy facies, while the lagoon was responsible for creation of low-energy facies (Figure 5).

The lagoon sub-environment is marked by the presence of mud-dominated nature (mainly mudstone and wackestone), shallow water fauna (especially benthic foraminifer, gastropods and sponge spicule) and peloid grains. This region was strongly influenced by micro-organisms, which was inferred from the prevalence of micritic envelope coated most of grains. In addition, living organisms actively influenced the lagoon zone and bioturbation is prevalent in this sub environment. The shoal sub-environment is characterized by the existence of grain-dominated and high-energy facies nature (mainly packstone and grainstone) and the abundance of rudist debris. The formation, fragmentation and reworking of the rudist structures is prevalent in different parts of shoal.

\section{Conclusion}

The Sarvak Formation is the second largest petroleum reservoir horizons in the South and Southwest of Iran, mainly consists of carbonate successions. According to petrographic analysis and facies studied thirteen microfacies are identified in the Sarvak formation in the studied area, that are grouped in three facies groups including 


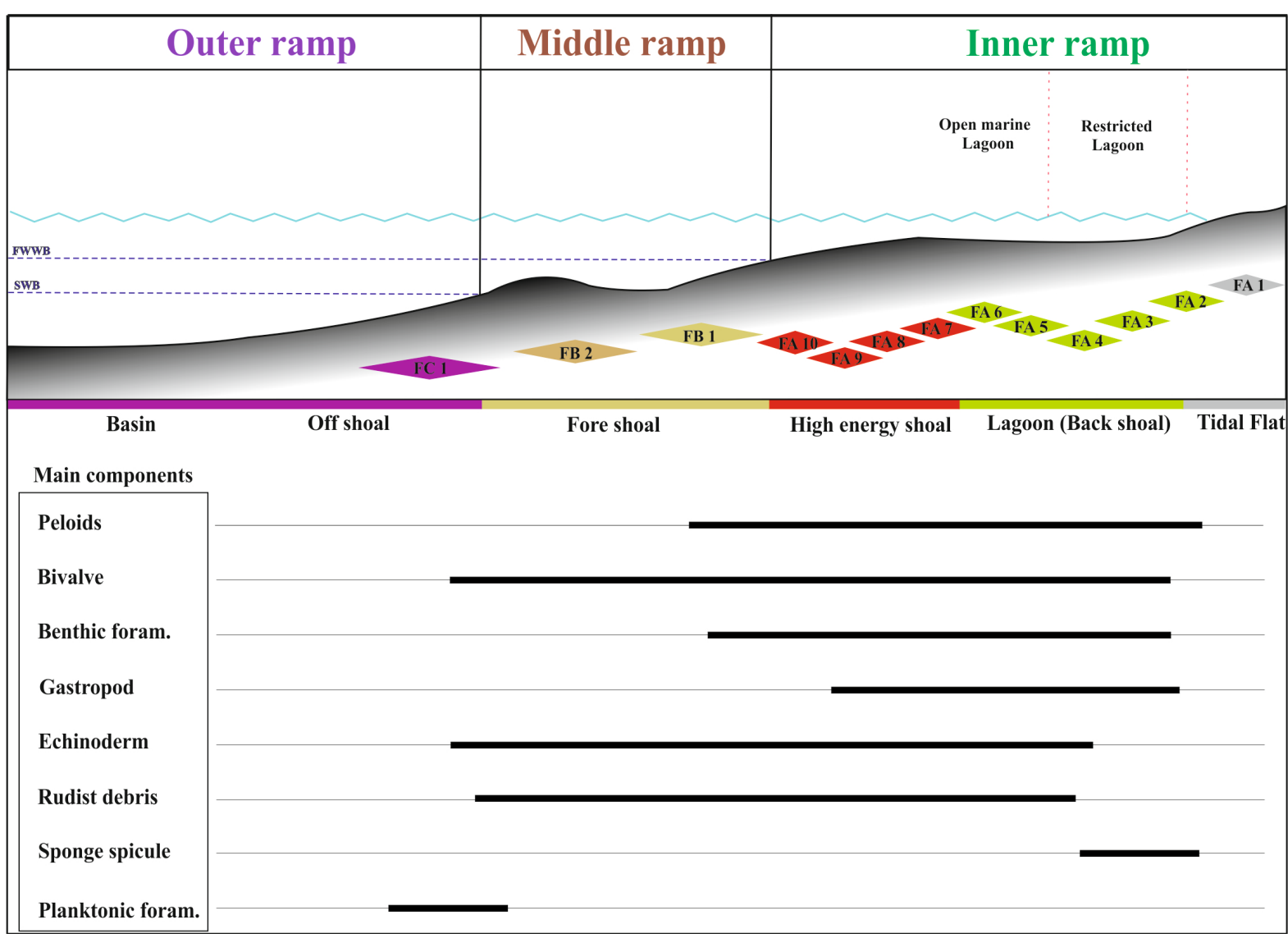

Figure 5. Schematic depositional model of the Sarvak Formation in the study area. Facies classification, grain distribution and sub-environment arrangement are shown on model.

inner ramp, mid ramp and outer ramp. Thus, depositional environment of the Sarvak formation is a carbonate ramp with gentle slope that is composed of different sub-environments such as tidal flat, lagoon and rudist shoal, fore shoal and off-shoal.

\section{Acknowledgements}

The authors acknowledge the Department of geology, Islamic Azad University, Science and Research branch, Tehran, Iran for funded this project. In addition, we thank Vice-President for Research in Science and Research branch, Tehran. Thank the Petroleum Engineering and Development Company (PEDEC) for continuing support this project.

\section{References}

[1] Sharland, P.R., Archer, R., Casey, D.M., Davies, R.B., Hall, S.H., Heward, A.P., Horbury, A.D. and Simmons, M.D. (2001) Arabian Plate Sequence Stratigraphy: GeoArabia. Special Publication, 2, 371.

[2] James, G.A. and Wynd, J.G. (1965) Stratigraphic Nomenclature of Iranian Oil Consortium, Agreement Area. American Association of Petroleum Geologists Bulletin, 49, 2182-2245.

[3] Alsharhan, A. (1995) Facies Variation, Diagenesis, and Exploration Potential of the Cretaceous Rudist-Bearing Carbonates of the Arabian Gulf. American Association of Petroleum Geologists Bulletin, 79, 531-550. http://dx.doi.org/10.1306/8d2b1584-171e-11d7-8645000102c1865d

[4] Bashari, A. (2007) Integrated 3D Seismic and Petrophysical Data of the Sarvak Formation in the Persian Gulf. First Break, 25, 45-53.

[5] Bashari, A. (2007) Petrographic, Petrophysics and Seismic Integration: An Approach to Characterize Mishrif Reservoir on Reshadat Oil Field in the Persian Gulf. Geoscience Scientific Quarterly Journal, 16, 204-211. 
[6] Aleali, M., Feiznia, S. and Esmaeili, A. (2007) Sequence Stratigraphy of Sarvak Formation in North West of Behbahan (Maghar Valley). Applied Geology, 2, 80-86.

[7] Ghabeishavi, A., Vaziri-Moghaddam, H. and Taheri, A. (2009) Facies Distribution and Sequence Stratigraphy of the Coniacian-Santonian Succession of the Bangestan Palaeo-High in the Bangestan Anticline, SW Iran. Facies, 55, 243257. http://dx.doi.org/10.1007/s10347-008-0171-3

[8] Ghabeishavi, A., Vaziri-Moghaddam, H., Taheri, A. and Taati, F. (2010) Microfacies and Depositional Environment of the Enomanian of the Bangestan Anticline, SW Iran. Journal of Asian Earth Sciences, 37, 275-285. http://dx.doi.org/10.1016/j.jseaes.2009.08.014

[9] Sharp, I., Gillespie, P., Morsalnezhad, D., Taberner, C., Karpuz, R., Verges, J., Horbury, A., Pickard, N., Garland, J. and Hunt, D. (2010) Stratigraphic Architecture and Fracture-Controlled Dolomitization of the Cretaceous Khami and Bangestan Groups: An Outcrop Case Study, Zagros Mountains, Iran. In: Van Buchem, F.S.P., Gerdes, K.D. and Esteban, M., Eds., Mesozoic and Cenozoic Carbonate Systems of the Mediterranean and the Middle East e Stratigraphic and Diagenetic Reference Models, Geological Society, Special Publications, London, 329, 343-396.

[10] van Buchem, F., Gaumet, F., Védrenne, V. and Vincent, B. (2006) Middle East Cretaceous Sequence Stratigraphy Study. NIOC-IFP, Iran.

[11] van Buchem, F.S.P., Simmons, M.D., Droste, H.J. and Davies, R.B. (2011) Late Aptian to Turonian Stratigraphy of the Eastern Arabian Plate Depositional Sequences and Lithostratigraphic Nomenclature. Petroleum Geoscience, 17, 211222. http://dx.doi.org/10.1144/1354-079310-061

[12] Hollis, C. (2011) Diagenetic Controls on Reservoir Properties of Carbonate Successions within the Albiane Turonian of the Arabian Plate. Petroleum Geoscience, 17, 223-241. http://dx.doi.org/10.1144/1354-079310-032

[13] Rahimpour-Bonab, H., Mehrabi, H., Navidtalab, A. and Izadi-Mazidi, E. (2012) Flow Unit Distribution and Reservoir Modeling in Cretaceous Carbonates of the Sarvak Formation, Abteymour Oilfield, Dezful Embayment, SW Iran. Journal of Petroleum Geology, 35, 213-236. http://dx.doi.org/10.1111/j.1747-5457.2012.00527.x

[14] Mahdi, T.A. and Aqrawi, A.A.M. (2014) Sequence Stratigraphic Analysis of the Mid-Cretaceous Mishrif Formation, Southern Mesopotamian Basin, Iraq. Journal of Petroleum Geology, 37, 287-312. http://dx.doi.org/10.1111/jpg.12584

[15] Mehrabi, H., Rahimpour-Bonab, H., Enayati-Bidgoli, A.H. and Esrafili-Dizaji, B. (2015) Impact of Contrasting Paleoclimate on Carbonate Reservoir Architecture: Cases from Arid Permo-Triassic and Humid Cretaceous Platforms in the South and Southwestern Iran. Journal of Petroleum Science and Engineering, 126, 262-283. http://dx.doi.org/10.1016/j.petrol.2014.12.020

[16] Esrafili-Dizaji, B., Rahimpour-Bonab, H., Mehrabi, H., Afshin, S., Kiani Harchegani, F. and Shahverdi, N. (2015) Characterization of Rudist-Dominated Units as Potential Reservoirs in the Middle Cretaceous Sarvak Formation, SW Iran. Facies, 61, 14. http://dx.doi.org/10.1007/s10347-015-0442-8

[17] Motiei, H. (1993) Stratigraphy of Zagros. Geological Survey of Iran, 583 p.

[18] Jackson, J.A. and Mckenzie, D. (1984) Active Tectonics of the Alpine-Himalayan Belt between Western Turkey and Pakistan. Geophysical Journal of the Royal Astronomical Society, 77, 185-264. http://dx.doi.org/10.1111/j.1365-246X.1984.tb01931.x

[19] Alavi, M. (2004) Regional Stratigraphy of the Zagros Fold-Thrust Belt of Iran and Its Proforeland Evolution. American Journal of Science, 304, 1-20. http://dx.doi.org/10.2475/ajs.304.1.1

[20] Falcon, N.L. (1974) Southern Iran: Zagros Mountains. Geological Society, London, Special Publications, 4, $199-211$. http://dx.doi.org/10.1144/GSL.SP.2005.004.01.11

[21] Berberian, M. (1995) Master "Blind” Thrust Faults Hidden under the Zagros Folds: Active Basement Tectonics and Surface Morphotectonics. Tectonophysics, 241, 193-224. http://dx.doi.org/10.1016/0040-1951(94)00185-C

[22] Dunham, R.J. (1962) Classification of Carbonate Rocks According to Depositional Texture. American Association of Petroleum Geologists Memorial No. 1, 108-121.

[23] Embry, A.F. and Klovan, J.E. (1971) A Late Devonian Reef Tract on Northeastern Banks Island, NWT. Bulletin of Canadian Petroleum Geology, 19, 730-781.

[24] Wilson, J.L. (1975) Carbonate Facies in Geological History. Springer, Berlin-Heidelberg, New York, 471. http://dx.doi.org/10.1007/978-1-4612-6383-8

[25] Reading, H.G. (Ed.) (1996) Sedimentary Environments: Processes, Facies and Stratigraphy. 3rd Edition, Blackwell Science, Oxford, 688.

[26] Tuker, M.E. (2001) Sedimentary Petrology. 3rd Edition, Blackwell, Oxford, 260.

[27] Pomar, L. (2001) Types of Carbonate Platforms: A Genetic Approach. Basin Research, 13, 313-334. http://dx.doi.org/10.1046/j.0950-091x.2001.00152.x

[28] Flugel, E. (2010) Microfacies of Carbonate Rocks, Analysis, Interpretation and Application. Springer, Berlin, 976. 
[29] Shinn, E.A. (1986) Modern Carbonate Tidal Flats: Their Diagnostic Features. Quarterly Journal of Colorado School of mines, 81, 7-35.

[30] Hardie, L.A. and Shinn, E.A. (1986) Carbonate Depositional Environments, Modern and Ancient Part 3: Tidal Flats. Colorado School of Mines Quarterly, 81, 1-74.

[31] Aleali, M., Rahimpour-Bonab, H., Moussavi-Harami, R. and Jahani, D. (2013) Environmental and Sequence Stratigraphic Implications of Anhydrite Textures: A Case from the Lower Triassic of the Central Persian Gulf. Journal of Asian Earth Sciences, 75, 110-125. http://dx.doi.org/10.1016/j.jseaes.2013.07.017

[32] Alsharhan, A.S. and Kendall, C.G.S.C. (2003) Holocene Coastal Carbonates and Evaporates of the Southern Arabian Gulf and Their Ancient Analogues. Earth-Science Reviews, 61, 191-243. http://dx.doi.org/10.1016/S0012-8252(02)00110-1

[33] Aleali, M., Rahimpour-Bonab, H., Moussavi-Harami, R., Jahani, D. and Asadi-Eskandar, A. (2013) Depositional Environment and Sequence Stratigraphy of the Kangan Formation in South Pars Field. Geosciences, 22, 65-74.

[34] Bachman, M. and Hirsch, F. (2006) Lower Cretaceous Carbonate Platform of Estern Levant (Galilee and the Golan Heights). Stratigraphy and Second-Order Sea Level Change. Cretaceous Research, 27, 487-512. http://dx.doi.org/10.1016/j.cretres.2005.09.003

[35] Bathurst, R.G.C. (1966) Boring Algae, Micrite Envelope and Lithification of Molluscan Biosparites. Geological Journal, 5, 15-32. http://dx.doi.org/10.1002/gj.3350050104

[36] Sadooni, F.N. and Alsharhan, A.S. (2003) Stratigraphy, Microfacies and Petroleum Potential of the Mauddud Formation (Albiane Cenomanian) in the Arabian Gulf Basin. American Association of Petroleum Geologists Bulletin, 87, 1653-1680. http://dx.doi.org/10.1306/04220301111

[37] Tucker, M.E. and Wright, V.P. (1990) Carbonate Sedimentology. Blackwell Scientific Publications, London, 482. http://dx.doi.org/10.1002/9781444314175 